\title{
The Overview of Knowledge, Belief, and Side Effects of Using Herbal Medicines in South Tangerang, Banten, Indonesia
}

\author{
Idzni Izzati ${ }^{1}$, Marvel $^{2 *}$, Ismiarni Komala ${ }^{3}$ \\ \{iznizza@gmail.com¹, marvel@uinjkt.ac.id², ikomala@uinjkt.ac.id ${ }^{3}$ \} \\ *corresponding author
}

Pharmacy Study Program , Faculty of Health Sciences, UIN Syarif Hidayatullah Jakarta, Ciputat, 15419. Indonesia ${ }^{1,2,3}$

\begin{abstract}
The use of herbal medicine is growing especially with the recommendation to go back to nature. This survey aims to overview the public knowledge, belief, and side effects of using herbal medicines in South Tangerang, Banten, Indonesia. This is an analytic survey with a cross-sectional method and measured by questionnaires $(n=414)$. Data analysis tests used are univariate and bivariate analysis. The result showed the majority of respondents had good knowledge of herbal medicines $(63.3 \%)$ and a high belief in herbal medicines $(72.2 \%)$. About $8.9 \%$ of respondents felt the side effect of using herbal medicine. The most side effect is digestive system disorders. In bivariate analysis, there was a correlation between gender $(\mathrm{p}=0.004)$ and job $(\mathrm{p}=0.013)$ with knowledge of herbal medicines and the correlation between age $(p=0.007)$, gender $(p=0.029)$, job $(p=0.013)$, and education $(p=0.001)$ with the belief of herbal medicines. Moreover, there was a correlation between the knowledge and belief of herbal medicine $(\mathrm{p}=0.001)$.
\end{abstract}

Keywords: belief, herbal medicines, knowledge, side effects, survey

\section{Introduction}

Herbal medicines are naturally occurring, plant-derived substances with minimal or no industrial processing that have been used to treat the illness. It includes herbs, herbal materials, herbal preparations, and finished herbal products, that contain as active ingredients parts of plants, or other plant materials, or combinations ${ }^{[1]}$. Herbal medicines are available in the form of powders, tablets, capsules, pills, or solutions. However, it is not currently available as an injection or aerosol ${ }^{[2]}$. According to WHO, herbal medicine has been widely used in the world for nearly 20 years ${ }^{[3]}$.

The behavior of medicines searching is carried out by individuals and groups. It so varies, including not doing anything, self-medicating, seeking treatment at herbal treatment facilities, buying drugs at drugstores or herbal drugstore, seeking treatment by visiting modern medical facilities operated by the government or private health institutions which are categorized into medical centers, community health center, and hospitals ${ }^{[4]}$. Seeking herbal medicine is one of the 
first steps taken to cure health problems. Herbal medicine users consider herbal medicine that using natural ingredients will not cause side effects. Besides, herbal medicine is also considered more economical and in certain cases more healing than modern medicine. But the use of herbal medicines must be accompanied by knowledge to lead the consumer to use in the right way and avoid unwanted things including the occurrence of side effects due to the wrong use of herbal medicines ${ }^{[5]}$.

Indonesian society has used herbal medicine that is known as jamu in treating various diseases for a long time. It is important to know the profile of their knowledge and belief in Indonesian herbal medicine and get a description of the side effects that appeared after herbal medicine consumption. In this research, we conduct a cross-sectional study to obtain a description of belief, knowledge, and the side effect of the use of herbal medicine. The population in this study are people who live in South Tangerang City, Banten, Indonesia

\section{Method}

\section{Type of Research}

This study used a cross-sectional research design or known as the collection of variable data to obtain a picture of people's beliefs, knowledge, and the side effects of using herbal medicines at a certain time ${ }^{[6]}$.

\section{Population and Sample}

The population in this study were all people who live in South Tangerang City and are 2069 years old who can use the gadget. Determination of the number of samples using the Lemeshow formula $^{[7]}$.

$$
\begin{aligned}
\frac{\mathrm{n}=\mathrm{Z}^{2} \mathrm{p}(1-\mathrm{p})}{\mathrm{d}^{2}} & =\frac{1.96^{2} \times 0.5(1-0.5)}{0.05^{2}} \\
& =386
\end{aligned}
$$

$\mathrm{n}=$ number of minimum samples

$\mathrm{Z}=\mathrm{z}$ score at $95 \%$ level of trust

$\mathrm{p}=$ maximum estimate

$\mathrm{d}=$ error rate

The minimum sample was 386 respondents. The sampling was conducted using the purposive sampling technique. Purposive sampling is a method of selecting samples based on certain characteristics that are considered to have a correlation with population characteristics ${ }^{[8]}$. The inclusion criteria were people who live in South Tangerang and 20-69 years old who can use the gadget. 


\section{Category}

Every correct answer on the questionnaire was given a value of 1, the wrong answer was given a value of 0 . The measurement scale for knowledge and belief could be categorized as follows: high if the respondent's value was $76 \%-100 \%$, medium if the respondent's value was $56 \%-75 \%$, and low if the respondent's value was $<56 \%{ }^{[9]}$

\section{Validity and Reliability}

The validity of the question can be found from Pearson Correlation (r). If $r$ count is more than $r$ table then the question is valid ${ }^{[10]}$. The reliability can be found by looking at the Cronbach's alpha coefficient. A data is reliable if the Cronbach's alpha ranges from 0.6 to 0.8 and the Corrected item-total Correlation is more than $0.2^{[11]}$.

\section{Univariate Analysis}

The purpose of this analysis is to see the distribution of each variable. Data processing using univariate analysis includes criteria for respondents (gender, age, education, occupation, income), belief and knowledge of herbal medicines, and side effects of using herbal medicines.

\section{Bivariate Analysis}

In this study, bivariate analysis was carried out by using the Chi-square test. If the p-value < 0.05 , it can be concluded that there is a correlation between the variables. Meanwhile, if the p-value $>0.05$ it means that the statistical calculation results are not significant or there is no significant correlation between the two variables ${ }^{[10]}$.

\section{Result}

\section{Validity and Reliability}

The validity and reliability test was carried out by distributing questionnaires to 40 samples $(\mathrm{n}=40, \mathrm{df}=38)$ with a significance level of $5 \%$ then obtained $\mathrm{r}$ table 0.312 . The validity result is shown in table 1 and the reliability result is shown in table 2.

\section{Univariate Analysis}

Out of a total of 414 respondents, 294 were females and 120 were men. The age distribution of respondents was mostly in the range between 20-29 years old (75.1\%). Most participants were students of the college (56.3\%). Based on the level of education, it can be seen that most of the correspondence was senior high school, with a total of 196 respondents $(47.3 \%)$. While the distribution of respondents based on the highest level of income is at a value of $<$ Rp.2,000,000 with a total of 260 respondents $(62.8 \%)$. 
Table 1. Validity Result

\begin{tabular}{|c|c|c|c|}
\hline Question & $\mathrm{R}$ result & R table & Conclusion \\
\hline \multicolumn{4}{|c|}{ Knowledge Variable } \\
\hline Question 1 & 0.423 & 0.312 & Valid \\
\hline Question 2 & 0.583 & 0.312 & Valid \\
\hline Question 3 & 0.465 & 0.312 & Valid \\
\hline Question 4 & 0.711 & 0.312 & Valid \\
\hline Question 5 & 0.521 & 0.312 & Valid \\
\hline Question 6 & 0.494 & 0.312 & Valid \\
\hline Question 7 & 0.670 & 0.312 & Valid \\
\hline Question 8 & 0.482 & 0.312 & Valid \\
\hline \multicolumn{4}{|c|}{ Belief Variable } \\
\hline Question 1 & 0.747 & 0.312 & Valid \\
\hline Question 2 & 0.569 & 0.312 & Valid \\
\hline Question 3 & 0.687 & 0.312 & Valid \\
\hline Question 4 & 0.747 & 0.312 & Valid \\
\hline Question 5 & 0.795 & 0.312 & Valid \\
\hline Question 6 & 0.632 & 0.312 & Valid \\
\hline
\end{tabular}

Table 2. Reliability Result

\begin{tabular}{llll}
\hline Variable & $\mathrm{N}$ & Cronbach's Alpha & Conclusion \\
\hline Knowledge & 8 & 0.644 & Reliable \\
Belief & 6 & 0.782 & Reliable \\
\hline
\end{tabular}

In testing the public knowledge of herbal medicines, respondents were asked about general knowledge of herbal medicine, type of herbal medicine, and the use of herbal medicine. The distribution of the level of public knowledge of herbal medicine is shown in table 3.

Table 3. Distribution of Knowledge Level

\begin{tabular}{lll}
\hline Category & $\mathrm{N}$ & Percentage (\%) \\
\hline High & 262 & 63.3 \\
Medium & 137 & 33.1 \\
Low & 15 & 3.6 \\
\hline
\end{tabular}

For testing the public belief of herbal medicine, respondents were asked about the safety of herbal medicines, the benefit of herbal plants, and the repetition of using herbal medicines. The distribution of the level of public belief in herbal medicine is shown in table 4 . 
Table 4. Distribution of Belief Level

\begin{tabular}{lll}
\hline Category & $\mathrm{N}$ & Percentage (\%) \\
\hline High & 299 & 72.2 \\
Medium & 75 & 18.1 \\
Low & 40 & 9.7 \\
\hline
\end{tabular}

In the test about the efficacy and side effects of using herbal medicines, respondents were asked some questions. Based on the distribution of respondents' answers, it is known that from 414 respondents there are $330(79.7 \%)$ respondents who stated that herbal medicine can cure the diseases experienced by respondents, $39(9.4 \%)$ respondents stated the opposite, and $45(10.9 \%)$ respondents did not answer because they never used herbal medicine. Out of 414 respondents, there were 37 (8.9\%) who had experienced side effects. Out of all respondents who had experienced side effects, the most common side effect experienced by respondents was disorders of the digestive system that experienced by $25(71.4 \%)$ respondents. The side effects of respondents using herbal medicine can be seen in table 5 .

Table 5. Side Effects of Using Herbal Medicine

\begin{tabular}{lll}
\hline Side Effects & n & Percentage (\%) \\
\hline Digestive system disease & 25 & 71.4 \\
Skin disease & 4 & 11.4 \\
Kidney disease & 2 & 5.7 \\
Urinary disease & 2 & 5.7 \\
Nervous system disease & 2 & 5.7 \\
Drowsiness & 1 & 2.9 \\
Reproductive system diseases & 1 & 2.9 \\
Respiratory system disease & 1 & 2.9 \\
Ears, nose, throat, and eyes & 1 & 2.9 \\
Cardiovascular disease & 1 & 2.9 \\
Decrease desire to eat & 1 & 2.9 \\
\hline
\end{tabular}

Out of the 37 (8.9\%) respondents who had experienced side effects, there were 7 (18.9\%) respondents who reported side effects. Most respondents reported side effects to the doctor (71.4\%). Out of the $30(81.1 \%)$ respondents who did not report the side effects, $24(80 \%)$ of them did not report because they felt it was not important to be reported. If one day the respondent feels the side effects of the herbal medicine, most respondents think that they will continue to use herbal medicine because they think that each drug has side effects so it does not matter if there are side effects that are felt. Respondents who chose this answer were 184 (44.4\%). If one day the respondent feels the side effect of the herbal medicine being consumed, the most preferred action by the respondent is to immediately consult a doctor with a total of 283 respondents $(68.4 \%)$ who chose that action. 


\section{Bivariate Analysis}

The results of this analysis indicate whether there is a correlation between the respondent's characteristics with the respondent's level of belief and knowledge. The correlation of respondent characteristics with the belief can be seen in table 6 . From table 6 it can be informed that there was a correlation between age, gender, occupation, and education with belief because the p-value of it was more than 0.05 . Complete data of the correlation of respondent characteristics with knowledge can be seen in table 7. From table 7 it can be informed that there was a correlation between gender and knowledge, and occupation with knowledge because the $p$-value of it was more than 0.05 . The correlation between the knowledge and belief level of respondents about herbal medicine can be seen in table 8.

Table 6. Correlation of Respondent Characteristics with Belief Level

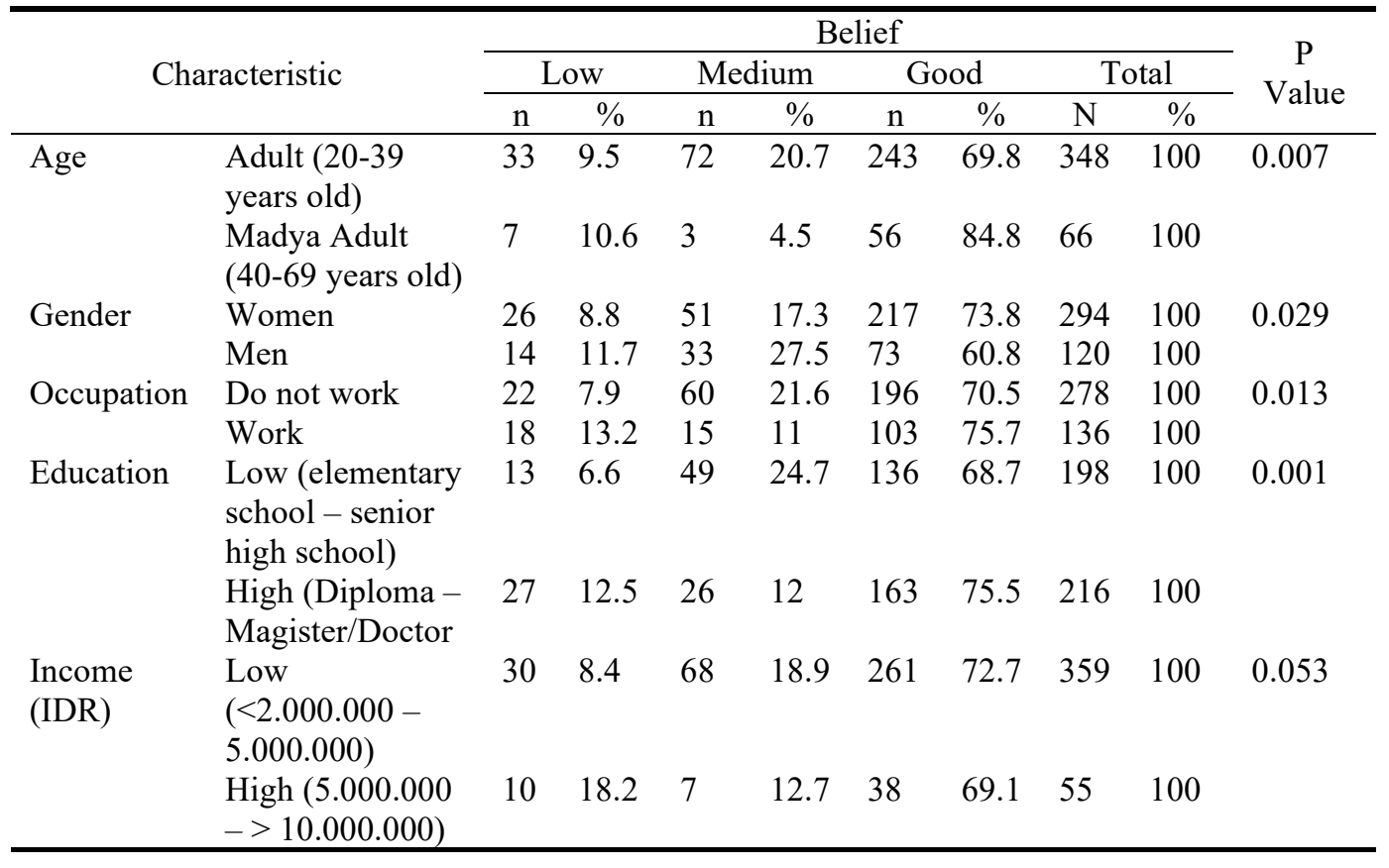


Table 7. Correlation of Respondent Characteristics with Knowledge Level

\begin{tabular}{|c|c|c|c|c|c|c|c|c|c|c|}
\hline \multirow{3}{*}{\multicolumn{2}{|c|}{ Characteristic }} & \multicolumn{8}{|c|}{ Knowledge } & \multirow{3}{*}{$\begin{array}{c}\mathrm{P} \\
\text { Value }\end{array}$} \\
\hline & & \multicolumn{2}{|c|}{ Low } & \multicolumn{2}{|c|}{ Medium } & \multicolumn{2}{|c|}{ Good } & \multicolumn{2}{|c|}{ Total } & \\
\hline & & $\mathrm{n}$ & $\%$ & $\mathrm{~N}$ & $\%$ & $\mathrm{n}$ & $\%$ & $\mathrm{~N}$ & $\%$ & \\
\hline \multirow[t]{2}{*}{ Age } & $\begin{array}{l}\text { Adult (20-39 } \\
\text { years old) }\end{array}$ & 12 & 3.4 & 123 & 35.3 & 213 & 61.2 & 348 & 100 & 0.081 \\
\hline & $\begin{array}{l}\text { Madya Adult } \\
\text { (40-69 years } \\
\text { old) }\end{array}$ & 3 & 4.5 & 14 & 21.2 & 49 & 74.2 & 66 & 100 & \\
\hline \multirow[t]{2}{*}{ Gender } & Women & 5 & 1.7 & 96 & 32.7 & 193 & 65.6 & 294 & 100 & 0.004 \\
\hline & Men & 10 & 8.3 & 41 & 34.2 & 69 & 57.5 & 120 & 100 & \\
\hline \multirow[t]{2}{*}{ Occupation } & Do not work & 11 & 4 & 92 & 33.1 & 175 & 62.9 & 278 & 100 & 0.013 \\
\hline & Work & 4 & 2.9 & 45 & 33.1 & 87 & 64 & 136 & 100 & \\
\hline \multirow[t]{2}{*}{ Education } & $\begin{array}{l}\text { Low } \\
\text { (elementary } \\
\text { school - senior } \\
\text { high school) }\end{array}$ & 7 & 3.5 & 65 & 32.8 & 126 & 63.6 & 198 & 100 & 0.988 \\
\hline & $\begin{array}{l}\text { High (Diploma } \\
-\end{array}$ & 8 & 3.7 & 72 & 33.3 & 136 & 63 & 216 & 100 & \\
\hline \multirow[t]{2}{*}{$\begin{array}{l}\text { Income } \\
\text { (IDR) }\end{array}$} & $\begin{array}{l}\text { Magister/Doctor } \\
\text { Low } \\
(<2.000 .000- \\
5.000 .000)\end{array}$ & 13 & 3.6 & 122 & 34 & 224 & 62.4 & 359 & 100 & 0.611 \\
\hline & $\begin{array}{l}\text { High }(5.000 .000 \\
->10.000 .000)\end{array}$ & 2 & 3.6 & 15 & 27.3 & 38 & 69.1 & 55 & 100 & \\
\hline
\end{tabular}

Table 8. Correlation of Knowledge and Belief level

\begin{tabular}{llccccccc}
\hline \multirow{2}{*}{ Characteristic } & \multicolumn{4}{c}{ Belief } & \multicolumn{3}{c}{} \\
& & \multicolumn{2}{c}{ High } & \multicolumn{2}{c}{ Medium and low } & \multicolumn{2}{c}{ Total } & P Value \\
& & $\mathrm{n}$ & $\%$ & $\mathrm{n}$ & $\%$ & $\mathrm{~N}$ & $\%$ & \\
\hline \multirow{2}{*}{ Knowledge } & High & 204 & 77.9 & 58 & 22.1 & 262 & 100 & \multirow{2}{*}{0.001} \\
\cline { 5 - 10 } & Medium and low & 95 & 62.5 & 57 & 37.5 & 152 & 100 & \\
\hline
\end{tabular}

\section{Discussion}

This survey described knowledge, belief, and side effect of using herbal medicine in South Tangerang. Of 414 respondents who have a good level of knowledge of herbal medicine are 262 respondents (63.3\%). Meanwhile, 137 respondents (33.1\%) had medium knowledge and 15 respondents (3.6\%) had low knowledge. For the belief in herbal medicine, 299 respondents $(72.2 \%)$ had a good or high level of belief in herbal medicine. People who had a medium level of belief were 
75 respondents (18.1\%) and people with a low level of belief were 40 respondents $(9.7 \%)$. In bivariate analysis, there was a correlation between gender and knowledge. Women respondents have a higher level of knowledge than men. This can be caused by women who are more at home or become housewives so they care more about health ${ }^{12]}$. There was also a correlation between occupation and knowledge. There was a difference in the level of knowledge about herbal medicine between working and non-working people. This can be caused by people who work will get more information because they tend to meet other people more often ${ }^{[13]}$. There was not a correlation between age and knowledge. The majority of respondents who are at a productive age develop their perceptive power and mindset so that it is easier to find information about herbal medicine. However, elderly respondents also indicated that the respondents already had a lot of experience in medicine so information about herbal medicine was obtained ${ }^{[14]}$. There was not a correlation too between education and knowledge. This is not the same with the opinion of Nodoatmodjo (2014) which states that the higher the level of education, the more information is entered and the better the knowledge is obtained ${ }^{[15]}$. There was also not a correlation between income and knowledge. This is in accordance with the statement of Jennifer (2015), where people with high incomes do not necessarily have more information about herbal medicine, depending on the sector of work and the environment $^{[16]}$

There was a correlation between age and belief. The elderly population will tend to use herbal medicine more than the non-elderly population ${ }^{[16]}$. In the gender variable, more women respondents believe in herbal medicine than men. This is in accordance with Oktarlina's research. Women are considered more concerned about health than men so that women will tend to find out more about treatment, including herbal medicine ${ }^{[12]}$. There was also a correlation between job and belief. People who work more believe in herbal medicine. While working, respondents can interact with many people so that respondents can get a lot of information and recommendations about herbal medicine ${ }^{[13]}$. There was a correlation between education and belief. Respondents with low education have a higher belief in herbal medicine than people with higher education. The higher education level is more careful in choosing treatment and tends to choose the treatment that is safe, appropriate, and rational so that respondents with higher education tend to choose modern medicine over herbal medicine ${ }^{[13]}$

There was not a correlation between income and belief. This is not in accordance with the research conducted by Ismail's research where the level of income affects the level of belief. People with high incomes prefer to go to a doctor or medical personnel to check and choose modern medicine according to their complaints. On the other side, for less fortunate people, the first step to treating their disease is to make their own medicine from natural ingredients that they believe can cure. People with low income choose herbal medicines because the price is more affordable than modern medicine ${ }^{[17]}$

There was a correlation between knowledge and belief level. The better the knowledge, the higher the public's belief in herbal medicine. This is in accordance with Ismail's (2015) research which states that the more information that the public gets about herbal medicines, the more people that choosing herbal medicine will increase ${ }^{[17]}$. 


\section{Conclusion}

From this research, it can be concluded that the respondents had good knowledge of herbal medicines $(63.3 \%)$ and a high belief in herbal medicines $(72.2 \%)$. There was a correlation between gender $(\mathrm{p}=0.004)$ and job $(\mathrm{p}=0.013)$ with knowledge of herbal medicines and the correlation between age $(p=0.007)$, gender $(p=0.029)$, job $(p=0.013)$, and education $(p=0.001)$ with the belief in herbal medicines. Moreover, there was a correlation between the knowledge and belief of herbal medicine $(\mathrm{p}=0.001)$. About $8.9 \%$ of respondents felt the side effect of using herbal medicine and the most viable side effect is digestive system disorder.

\section{References}

[1] World Health Organization (WHO): Herbal medicine research and global health: an ethical analysis. retrieved June 11, 2020. Accessed from https:/www.who.int/bulletin/volumes/86/8/07-042820/en/ $\underline{(2005)}$

[2] H.R Dewoto: Pengembangan Obat Tradisional Menjadi Fitofarmaka. Majalah Kedokteran Indonesia, vol. 7, no. 7, pp. 205-211. doi: 10.24960/jli.v5il.667.53-59 (2007)

[3] Sulfiyana H. Ambo Lau; Herman; Rahmat M.: Studi Perbandingan Tingkat Pengetahuan Masyarakat Tentang Obat Herbal Dan Obat Sintetik Di Campagayya Kelurahan Panaikang Kota Makassar. J. Farm. Sandi Karsa, Vol. 5, no. 1, pp. 33-37(2019)

[4] Notoatmodjo: Ilmu Perilaku Kesehatan. Jurnal Dunia Kesehatan, vol.2 (2010)

[5] Maryani: Factor in Decision Making for Buying Jamu Scientific. Pusat Penelitian dan Pengembangan Humaniora dan Manajemen Kesehatan, pp.201 (2016)

[6] Wahyuningrum, Sri Rizki: Statistika Pendidikan. Jakad Media Publishing, Surabaya (2014)

[7] Riyanto, Slamet: Metode Riset Penelitian Kuantitatif Penelitian di Bidang Manajemen, Teknik, Pendidikan dan Eksperimen. Dee Publish, Yogyakarta (2020)

[8] Eriyanto: Teknis Sampling Analisis Opini Publik. LKLS, Yogyakarta (2007)

[9] Masturoh, Imas, and Nauri Anggita T: Metodologi Penelitian Kesehatan. Kementrian Kesehatan RI, Jakarta (2018)

[10] Hulu, Victor Trismanjaya: Analisis Data Statistik Parametrik Aplikasi SPSS dan Statcal. Penerbit Yayasan Kita Menulis, Sumatera Utara (2019)

[11] Sufren, et al.: Belajar Otodidak SPSS Pasti Bisa. Penerbit PT Elex Media Komputindo, Jakarta (2014)

[12] R. Z. Oktarlina, A. Tarigan, N. Carolia, and E. R. Utami: Hubungan Pengetahuan Keluarga dengan Penggunaan Obat Tradisional di Desa Nunggalrejo Kecamatan Punggur Kabupaten Lampung Tengah. JK Unila, Vol. 2, no. 1, pp. 42-46 (2018)

[13] S. A. Kristina, Y. S. Prabandanri, and R. Sudjaswadi: Perilaku pengobatan sendiri yang rasional pada masyarakat. Berita Kedokteran Masyarakat, vol. 23, no. 4, pp. 176-183 ( 2007)

[14] R. S. Dewi, F. Aryani, E. Pratiwi, and T. T. Agustini: Persepsi Masyarakat Mengenai Obat Tradisional di Kecamatan Tampan Kota Pekanbaru. Penelit. Farm. Indones., vol. 8, no. 2 (2019)

[15] Notoatmodjo: Ilmu Perilaku Kesehatan. Jurnal Dunia Kesehatan, no. 2 (2012)

[16] H. Jennifer and E. Saptutyningsih: Preferensi Individu Terhadap Pengobatan Tradisional di Indonesia. J. Ekon. dan Stud. Pembang., vol. 16, no. 1, pp. 26-41 (2015)

[17] I. Ismail: Faktor Yang Mempengaruhi Keputusan Masyarakat Memilih Obat Tradisional Di Gampong Lam Ujong. Idea Nurs. J., vol. 6, no. 1, pp. 7-14 (2015) 